\title{
3
}

\section{Toleration and the character of pluralism}

\author{
Catriona McKinnon
}

This chapter addresses two influential ways of thinking about which political principles we ought to adopt. The first way of thinking starts with expectations about how persons ought to relate to one another in political discourse. Political principles are justified by reference to these expectations. The second way of thinking starts with certain values around which, it is claimed, people ought to structure their lives. Political principles are then justified by reference to these values. These approaches to political justification are in competition, and arguments for political principles of toleration and beyond can be made on either approach.

In the work of John Rawls we find an example of the first, 'constructivist', approach. Constructivist values are taken to be appropriate in political justification because people exercising their practical reason to solve shared problems of justice would be committed to these values. Constructivist justificatory values are the values of people who aim at peaceful co-existence and profitable cooperation in political society. Different accounts of what counts as peaceful co-existence and, especially, profitable cooperation yield different constructivist values. ${ }^{1}$ I shall offer an interpretation of Rawls whereby political principles of toleration and beyond are justified in virtue of the legitimate expectation that citizens themselves move beyond toleration in their political discourse by engaging with one another in public reason.

In the work of Joseph Raz we find an advocate of the second, 'perfectionist', approach. Perfectionist justificatory values are to be found in a true moral theory, or true faith, and are claimed to be appropriate as justificatory values in virtue of their place in a true moral theory, or true faith. Raz argues for multiculturalist political principles that transcend toleration by appeal to the perfectionist value of personal autonomy. On this approach, we start with values embedded in a true moral theory and justify political principles by reference to these values, independent of the expectations we have of those to whom the principles are justified. 
My argument will be that one way of pinpointing what is at issue between perfectionist and constructivist political justifications is to examine assumptions about the character of pluralism that inform each approach. These assumptions relate to the interpersonal attitudes we can expect of people facing shared problems of justice in conditions of pluralism. I shall argue that these assumptions are not implicit in - and cannot be derived from assumptions about the nature of pluralism, but must instead be argued for separately. If, as Raz thinks, the most we can expect of persons in pluralism is toleration, then the justification of political principles beyond toleration - for example, his multiculturalist principles - cannot be constructed from expectations about the interpersonal attitudes people will adopt in pluralism. This makes sense of Raz's perfectionist appeal to a true moral theory to support justificatory values beyond political toleration. Raz drives a wedge between what we can expect of persons and what we can justify as a matter of political principle with certain claims about the inevitability and appropriateness of conflict and hostility between people facing political problems, whereas these assumptions are absent from Rawls's constructivism. If Raz's claims are true then Rawls's approach is undermined, because the expectations of persons upon which it relies are unrealistic or inappropriate. If the most that can be expected of citizens is toleration then the logic of an appeal to perfectionist values to justify political principles beyond toleration is clarified and the perfectionist approach to political justification becomes more attractive.

Let me clear the ground for this argument by making some brief remarks, in the next section, on the relationship between toleration qua personal attitude and toleration qua political principle.

\section{Toleration: political and personal}

Toleration can be conceived as a personal attitude or as a political principle. All defences of toleration as a personal attitude or as a political principle consist of arguments to show that toleration is the appropriate response to people who differ from us, and whom we dislike or of whom we disapprove.

The object of toleration in the personal and political spheres is a disliked or disapproved of person. Persons to be tolerated can differ from us in terms of their values, practices, beliefs, ends, forms of community and association, dispositions, tastes, or preferences. By placing the personal and political concepts of toleration on spectrums of possible responses to disliked and disapproved of people we can clarify what toleration demands. On each scale, toleration marks a substantial shift of principle or attitude; each stage subsequent to toleration should be thought of as transcending the previous stage. Each stage represents a more positive set of responses to disliked and disapproved of differences than the preceding stage. 


\section{Toleration as a political principle}

\section{Repression}

Perhaps the historically most common political response to disliked and disapproved of people has been the attempt to crush them, repress them, or drive them out. Principles of repression are sometimes accompanied by a denial that the disliked and disapproved of person differs, deep down, from the repressor. But repression born of the denial of difference repudiates its own basis, as repression would be unnecessary if it were true that difference did not exist. However, not all political repression need contradict its own basis. Repressive states can admit the existence of disliked and disapproved of people and attempt to justify their repression of these people by asserting the superiority of a world in which these people cease to differ from their repressors, and the acceptability of the use of state coercion to bring about this state of affairs.

\section{Official discouragement}

Political agents who agree that a world free of disliked or disapproved of people is a better world, but who shrink from repression and the coercion required to create this world, might adopt a policy of official discouragement. Here the attempt is to impede access to ways of life incorporating the disliked or disapproved of differences without repressing people who already practise these ways of life. We can see the distinction between repression and official discouragement by considering certain policies towards homosexuality. The UK legislation overturned by the 1959 Wolfenden Report was repressive: in making homosexual sex between men a crime this legislation aimed at preventing the practice of this kind of sex between existing gay men with the coercive power of the law. But there are ways of being intolerant of homosexual people without attempting to repress them, as evinced in Section 28 of the Local Government Bill in the UK. ${ }^{2}$ Section 28 does not explicitly attempt to repress homosexual activity between gay people but aims instead to restrict the flow of information about homosexuality, and thereby indirectly to discourage young and closeted people from reflecting on their sexual preferences.

\section{Toleration}

Toleration of disliked or disapproved of people requires refraining from repression and official discouragement of the practices constitutive of these differences. Because interference can take the form of direct coercion, as in the case of repression, or insidious distortion, as in the case of discouragement, a political principle of toleration demands refraining from both. Principles of toleration are adopted by states when they refuse to interfere with peoples' pursuit of life styles associated with the disliked or disapproved of differences by means of force or propaganda. But a tolerant society need not be one in which people who differ from the majority in disliked or dis- 
approved of ways are invited to participate in the major political and social institutions of that society. The political principle of toleration is negative: it demands restraint with respect to the use of state power as it affects people who lead lives disliked or disapproved of by the majority, or by those with the most political power. Of course, no thinker recommends that the scope of political toleration be unlimited. Dislike and disapproval are often responses to aspects of persons causing genuine harm to others, or to society. To accommodate these cases many thinkers use a 'harm principle' to set the limits of toleration; where they disagree is on what constitutes harm.

\section{Political inclusion}

Toleration only demands action when abstention has not been observed, so as to put right the wrongs of official discouragement or repression. But political responses to disliked and disapproved of people can go beyond toleration. In addition to refraining from using political means to interfere with citizens' pursuit of disliked and disapproved of lifestyles, the state can also attempt to include these people in its major political, social and economic institutions. This principle can be used to justify equal opportunities legislation, including policies of positive discrimination and quota systems. It can also underpin certain policies in education such as citizenship education, which asks that children be made to cultivate a range of skills necessary for good citizenship and a healthy degree of participation and interest in the political life of their society. Most non-libertarian political philosophers endorse some principles of political inclusion.

\section{Official promotion}

A final possibility is that the state actively promotes the differences that prompt dislike and disapproval in the institutions of civil society. Policies designed to preserve minority languages, to protect opportunity for religious worship and traditional dress through restrictions on employment legislation and schooling requirements, and to enable same-sex and religion-based polygamous marriages can all be justified by reference to principles of official promotion. Official promotion is a strong principle variously defended as demanded by equal opportunity for self-respect, a concern for the conditions of personal autonomy, equal concern and respect, and recognition of relationship between individual freedom and an agent's social context, and other liberal and communitarian ideals.

\section{Personal toleration}

\section{Repression}

As at the political level, a common response to disliked and disapproved of people at the personal level is an attempt to repress them. Repression is often motivated by hatred of others, disgust at their way of life, or simple 
indifference towards them. However, repression is also sometimes practised in the name of the salvation, character, or well-being of the repressed person. As at the political level, repression at the personal level is sometimes accompanied by the claim that the repressed person is actually no different at heart from the repressor, and is contradictory in the same way.

\section{Toleration}

The personal attitude of toleration demands a principled refusal to interfere with disliked or disapproved of people so as to change the aspects of the person that prompt dislike or disapproval. ${ }^{3}$ The personal attitude of toleration demands the principled avoidance of the use of force against persons to eradicate their disliked or disapproved of differences. It also prohibits the use of propaganda at the personal level. As well as refraining from physical coercion as a way of changing the disliked or disapproved aspects of a person, the tolerant person does not engage in verbal bullying of people whom she dislikes and of whom she disapproves. This is not to say that the tolerant person does not attempt to persuade the person whom she tolerates of the error of her ways. But there is an important difference (often hard to discern) between persuasion and harassment. Anti-abortionists who picket abortion clinics may conceive of themselves as attempting to persuade women entering the clinics of the error of their ways; but arguably they are actually harassing these women. Although personal toleration is compatible with attempts at persuasion, such engagement is not demanded by personal toleration. People can exhibit the virtue of toleration by simply minding their own business. As at the political level, no thinker argues that toleration at the personal level is appropriate with respect to all disliked and disapproved of people. Some disliked and disapproved of people are intolerable.

\section{Engagement}

Moving beyond toleration, the next level of response to disliked and disapproved of people is an attempt to engage with them as disliked and disapproved of people (i.e. without denial of their differences). The attitude of engagement demands that a person attempt to understand the values, practices, beliefs, ends, forms of community and association, dispositions, tastes, or preferences of people whom she dislikes and of whom she disapproves, either by attempting to engage them in some kind of discussion about their differences, or by imaginatively reconstructing their point of view. Engagement requires empathy and an attempt at interpretation of the other person's situation so as to understand the meaning of the symbols, practices, exchanges, and language that constitute that situation. But a person's engagement with another does not require that she come to a complete understanding of the person whom she dislikes and of whom she disapproves, let alone that she overcome her dislike or disapproval. 
Engagement simply requires that a person genuinely attempt to understand the disliked and disapproved of other in terms of her beliefs, motivations, the relationship between her beliefs and motivations, her history, her biography, her self-image, and her values.

As with toleration, it is not the case that engagement is always appropriate. The limits of engagement might be set with the harm principle associated with toleration (remembering that engagement transcends toleration) in conjunction with some 'comprehensibility' principle. The comprehensibility principle would establish the extent to which persons can, or ought to, engage with disliked and disapproved of others by specifying the points at which another's beliefs or behaviour become incomprehensible. Some insane people might be beyond the limits of engagement in virtue of their cognitive disorder; some very evil people might exceed these limits in virtue of the monstrous nature of their values and preferences.

\section{Appreciation}

The final level of personal response to difference asks that people overcome their dislike of one another even in the face of their disapproval of one another. Friendship, family relations, and relations of love can all involve attitudes of appreciation. Appreciation does not demand that a person deny her differences with others. Such denials are damaging; when one person subsumes her identity in the identity of another it is a sign of an unhealthy relationship, not devoted love.

With these rough scales of response to difference in place, we can isolate three key questions of political justification:

1 What sorts of political principles are justified in conditions of permanent pluralism?

2 What sorts of personal attitudes can we legitimately expect people to adopt in response to one another in conditions of permanent pluralism?

3 How, if at all, do the attitudes specified in (2) affect the justification of principles specified in (1)?

With respect to (1), no political philosopher on the contemporary scene defends political principles of repression. Some thinkers defend political principles of official discouragement, but such defences are rare. Most contemporary political philosophers defend some principles of toleration, and all non-libertarian liberal thinkers defend some principles beyond toleration. The principles specified in answer to (1) will in some part provide an answer to (2): people ought to adopt those attitudes demanded by the political principles of (1). With respect to question (3), one way of seeing how the attitudes specified in answer to (2) must affect the principles specified in answer to (1) is through examination of the argument for political toleration from pluralism. This argument purports to justify political principles of toleration without reference to personal attitudes of toleration, and by reference only to the incommensurable nature of the differences that 
contribute to pluralism. In criticism of this argument I shall show that some assumptions about citizens' personal attitudes must be made before political toleration can be claimed to be appropriate. Revealing these assumptions shows that reflections on the nature of pluralism are a red herring with respect to arguments for political toleration: in making such arguments, we must focus instead on the character of pluralism.

\section{Toleration and the nature of pluralism}

Pluralism is a view about the nature of the differences between people to which personal attitudes and political principles of toleration respond. Pluralists argue that many differences between values, ends and options are incommensurable in two important senses. First, many different values, practices, ends, or forms of association are not realisable within the life of a single person or a single community (the thesis of practical incompatibility). And second, it makes no sense, or is inappropriate, to compare many different values, practices, ends or forms of association in terms of their value (the thesis of evaluative incomparability). ${ }^{4}$ For Raz, the 'mark of incommensurability' is a failure of transitivity with respect to the value of certain options (ends, values, practices, etc.). ${ }^{5}$

Two valuable options are incommensurable if (1) neither is better than the other, and (2) there is (or could be) another option that is better than one but is not better than the other. ${ }^{6}$

Taking two options, A and B, the failure of transitivity in (1) shows that $\mathrm{A}$ and $\mathrm{B}$ per se cannot compared in terms of their value, and the failure of transitivity in (2) shows that there is no master-value $\mathrm{C}$ that enables comparison of A and B in terms of their value. Raz's account of evaluative incomparability improves on Isaiah Berlin's famous account. Berlin took the denial of evaluative incomparability to entail the assertion of a mastervalue making possible evaluative comparisons. But Raz makes it clear that options are incommensurable both when they cannot be ranked by reference to a master-value, and when they simply cannot be ranked. ${ }^{7}$ The denial of evaluative incomparability does not entail the assertion of a master-value.

The argument from pluralism for political principles of toleration is as follows:

1 Given incommensurability conflict between those with different ends and values is a permanent feature of the world.

2 Given incommensurability it is illegitimate to impose certain values and ends on people by restricting their negative liberty in such a way as to force or encourage the adoption of other preferred values and ends. ${ }^{8}$

3 Therefore, repression and official discouragement are illegitimate. Political principles of toleration are the least to which we ought to be committed. 
The argument is that if differences between people are inevitable and incommensurable then political principles of toleration will always be necessary to ensure that those with power do not use coercive force or propaganda to attempt illegitimately to eradicate those who differ from them. Political principles of toleration are necessary for preserving peace, stability and justice between people divided by incommensurable differences. ${ }^{9}$ This argument for toleration only succeeds given a commitment to individual freedom as negative in Berlin's sense. ${ }^{10}$ As my interest here is in the liberal tradition, and all liberals place some value on negative liberty, I will not address this commitment (although we might ask what the truth of the thesis of evaluative incomparability would add to the normative injunction in (2)). Instead, I want to focus on a more serious flaw in the argument.

Political toleration is a response to disliked and disapproved of differences. However, the argument from pluralism does not establish that incommensurable differences will prompt dislike or disapproval. The two theses of incommensurability appearing as premises in the argument from pluralism assert the existence of ineradicable and evaluatively incomparable differences: they address the nature of pluralism. What they do not establish is the character of the disagreements between those separated by incommensurable differences. It could be the case that the two theses of incommensurability are true and yet political toleration is unnecessary: those separated by incommensurable differences might not dislike and disapprove of one another. Or it could be the case that the two theses of incommensurability are false and political toleration is necessary: those separated by commensurable differences might dislike and disapprove of one another. Given that the two theses of incommensurability do not establish that those separated by incommensurable differences will dislike and disapprove of one another, the argument for toleration from pluralism is a red herring. To understand the need for toleration, and the prospects for transcending it, requires an account of the character of pluralism. The focus of this account will be what personal attitudes towards disliked and disapproved of others can reasonably be expected of people. All arguments for political principles of toleration and beyond must operate with some assumptions about the character of pluralism. Examination of these assumptions as they appear in the work of Rawls and Raz explains their different approaches to the justification of political principles.

\section{The character of pluralism: the Rawlsian picture}

On Rawls's view, the values of political justification are derived from the exercise of persons' practical reason as it addresses principles securing the conditions for peaceful and profitable cooperation in political society. According to Rawls, people so conceived will address one another in public reason when attempting to solve their political problems. Rawls's conception of justice is justified to the extent that these expectations are legitimate. 
The only resources Rawls has for political justification are these expectations; Rawls denies that he need invoke any values beyond these expectations in order to justify his political principles. For citizens to address one another in public reason demands that they move beyond the personal attitude of toleration to attitudes of engagement.

For Rawls, a stable and just society is one in which there is an overlapping consensus among reasonable citizens on a conception of justice. Given the fact that pluralism is permanent, this conception of justice cannot be justified by reference to any one comprehensive moral, religious, or philosophical doctrine. Citizens who differ on questions of doctrine can nevertheless reach an overlapping consensus on a conception of justice by debating political questions in public reason. When citizens address one another in public reason they present their proposals to one another in terms that they reasonably expect one another to understand and accept, and are disposed to act on proposals agreed in public reason, given the assurance that all other citizens will also act on these principles: 'The point of the ideal of public reason is that citizens are to conduct their fundamental discussions within the framework of what each regards as a political conception of justice based on values that others can reasonably be expected to endorse, and each is, in good faith, prepared to defend that conception so understood. ${ }^{11}$

When citizens achieve the ideal of public reason they 'think of themselves as if they were legislators' in order to consider which principles and policies they would adopt using public reason. ${ }^{12}$ If they find a discrepancy between the principles and policies they would adopt in public reason, and the principles and policies adopted by their actual political representatives, then they have a duty to use democratic means to change the way in which their representatives legislate.

Rawls's public reason demands a personal attitude of engagement because it is realised in a process of deliberation between citizens. For a person to determine how to present her political proposals in public reason, where these proposals are informed by her religious, moral and philosophical beliefs, requires that she attempt to understand the religious, moral and philosophical beliefs informing the political proposals of others. Until she engages with others in this way she cannot engage in public reason. Admittedly, the degree of personal engagement demanded by Rawls's ideal of public reason is limited to the political sphere. But given that citizens' political proposals are informed by their non-political values and beliefs, public reason can demand a substantial degree of engagement with others on non-political issues. ${ }^{13}$ 'When citizens deliberate, they exchange views and debate their supporting reasons concerning public political questions. They suppose that their political opinions may be revised by discussion with other citizens: and therefore these opinions are not simply a fixed outcome of their existing private or nonpolitical interests. ${ }^{14}$ 
Rawls's description of how overlapping consensus might arise reveals a dynamic conception of relations between citizens in political community. In discussion of the sixteenth-century wars of religion he claims that the resolution of these wars with principles of religious toleration was not a result of an overlapping consensus on these principles, but rather the result of a certain balance of power (and some exhaustion) establishing a modus vivendi. ${ }^{15}$ Rawls argues that it is possible to move from such a modus vivendi, via a constitutional consensus, to an overlapping consensus, and that moving through these stages of consensus stimulates important changes in citizens' attitudes to one another. ${ }^{16}$

In a modus vivendi, citizens exhausted by war acquiesce to certain political principles of toleration. Recognising that these principles secure the important good of political stability for themselves and those they care for, citizens reach a constitutional consensus by coming to agree on liberal political principles guaranteeing certain basic political rights necessary for safeguarding democratic electoral procedures. Consensus on such a constitution requires the limited use of public reason: citizens affirm the constitution as a good for themselves and their fellow citizens, disregarding the balance of power between them.

The move from constitutional to overlapping consensus involves a broadening of the scope of the consensus and a deepening of the relations between the conception of justice and citizens' conceptions of the good. ${ }^{17}$ Once stable constitutional consensus is established, citizens make their political claims through the democratic procedures established by the constitution. Within the framework of minimal political rights necessary for a stable democracy, citizens discuss wider and more controversial questions of political inclusion and official encouragement. These involve a discussion of the distribution of rights to freedom of thought, expression and association per se, questions of distributive justice, the distribution of power and opportunity in society, and access to the social bases of self-respect. Citizens addressing one another in public reason on these questions of political inclusion and official encouragement must engage with one another on a level deeper than that required by stable constitutional consensus, because the questions of justice they discuss intersect with their comprehensive doctrines to a much greater degree than constitutional essentials. For example, in a diverse society there is likely to be far more disagreement over the appropriate patterns of economic redistribution than over the principle of universal suffrage. Overlapping consensus emerges when citizens agree on principles of justice to govern, not just the distribution of political rights attaching to democratic procedures, but also matters relating to the basic structure of society: its main political, social, and economic institutions. ${ }^{18}$ Citizens moving towards overlapping consensus on political principles beyond toleration must adopt personal attitudes of engagement that demand more than toleration. ${ }^{19}$ 
To sum up, the fact that Rawls's central justificatory tool - public reason - requires engagement on the part of citizens separated by differences shows that Rawls conceives of the ideal character of pluralism as non-hostile. Hostility involves a turning away from or rejection of another person: those separated by differences prompting hostility cannot engage in public reason. Debate in Rawls's public reason is only possible between those who differ - often to the extent of disliking and disapproving of one another - yet who are willing to make attempts at interpretation and understanding. The success of Rawlsian political justification relies on the claim that citizens ought to adopt attitudes of engagement. If it can be shown that citizens are incapable of adopting these attitudes, or ought not to adopt them, then the justification of liberal principles must proceed according to a different model.

\section{The character of pluralism: the Razian picture}

Raz's argument for political principles beyond toleration invokes the value of personal autonomy rather than the expectation that individuals themselves move beyond the personal attitude of toleration. On Raz's view, an appeal to perfectionist values in political justification is necessary because the competitive character of pluralism makes any expectations that people move beyond the personal attitude of toleration illegitimate. If this is true then our expectations of persons ought not to inform our justification of political principles beyond toleration, and Rawlsian constructivism in political justification is called into question.

Competitive pluralism not only admits the validity of distinct and incompatible moral virtues, but also of virtues which tend, given human nature, to encourage intolerance of other virtues. That is, competitive pluralism admits the value of virtues possession of which normally leads to a tendency not to suffer certain limitations in other people which are themselves inevitable if those people possess certain other, equally valid, virtues. ${ }^{20}$

The two theses of incommensurability asserted by Raz establish the inevitability of differences between persons in possession of different sets of virtues, and that evaluative comparisons between the options to which these virtues attach is often inappropriate. The claim that Raz adds to these theses with his characterisation of pluralism as competitive is that these conflicts will be accompanied by certain 'appropriate emotional or attitudinal concomitants or components' that make personal attitudes of engagement inappropriate. ${ }^{21}$ This is a claim about the character, rather than the nature, of pluralism.

Conflict is endemic ... pluralists can step back from their personal commitments and appreciate in the abstract the value of other ways of life and their attendant virtues. But this acknowledgement coexists with, and cannot replace, the feelings of rejection and dismissiveness towards what one knows is in itself 
valuable. Tension is an inevitable concomitant of accepting the truth of value pluralism. ${ }^{22}$

Raz thinks that in conditions of competitive pluralism the most we can legitimately ask of people whose ineradicable conflict with one another reaches beyond their values, beliefs, practices etc. to their moral emotions is the personal attitude of toleration. Given that the moral emotions attaching to conflicts between incommensurables are, according to Raz, entirely appropriate and not to be revised once an all-things-considered judgement about the conflict has been made by the agent, we cannot expect more of people than that they refrain from acting on these emotions.

Raz claims: 'I am not simply wrong in inclining to be intolerant of another person's meanness or vulgarity. These rightly trigger intolerant responses. A person who does not react to them in this way is lacking in moral sensibility. Yet it is a response which should be curbed. ${ }^{23}$

It is important to note that by characterising pluralism as competitive Raz is not simply making the claim that engagement has limits. All thinkers can agree on this point. By registering the sorts of differences that Raz thinks breed appropriate hostility it becomes clear that he conceives of pluralism as competitive both at the edges and at the centre. Ordinary vices like vulgarity, cultural differences, and even professional differences are Raz's examples of characteristics for which 'attitudunal concomitants' of hostility are appropriate. ${ }^{24}$ Hostility in Raz's competitive pluralism is not simply reserved - as it should be - for very bad people. Hostility permeates relations between those with different cultures, religions, professions, and weaknesses.

If toleration is the most we can ask of people as a personal attitude in conditions of competitive pluralism, can political principles beyond toleration be justified? Not on a model of political justification whereby principles are constructed from our reasonable expectations of citizens. But once the justification of political principles is detached from what we can legitimately expect of citizens, political principles beyond toleration become justifiable even when we can expect nothing but toleration from citizens.

Raz's argument for political principles of official encouragement - his multiculturalism - does not rely on the expectation that individuals as citizens ought to cultivate attitudes of engagement. ${ }^{25}$ Raz's argument for multiculturalism is consistent with the possibility that no person adopts an attitude of engagement towards those whom she dislikes and of whom she disapproves. Rather than offering multiculturalist principles as the object of an overlapping consensus between citizens discussing political questions in public reason, Raz argues for these principles by reference to the value of protecting the conditions of personal autonomy for all, which he takes to be a political value independent of expectations about how citizens ought to regard this value. ${ }^{26}$ Raz conceives of personal autonomy as achievable only in conditions in which a person has a certain minimum of mental 
faculties, a variety of adequate options from which to choose goals that will contribute to her well-being, and a degree of freedom from coercion. A principle of toleration (the 'harm principle') ensures freedom from coercion, and multiculturalist principles protect a variety of meaningful cultural options.

Raz's characterisation of pluralism as inevitably, appropriately and deeply competitive makes the expectation that citizens move beyond the personal attitude of toleration in their political discourse illegitimate. This characterisation of pluralism forces liberals to adopt forms of political justification that trace connections between moral values and political principles independent of the question of what sorts of attitudes we can expect from citizens.

If Rawls is right about the character of pluralism then it is not clear why we should invoke perfectionist values in justification of political principles beyond toleration. If Raz is right about the character of pluralism then we cannot avoid invoking perfectionist values in justification of political principles beyond toleration. To decide between these two approaches we need to know who is right about the character of pluralism. I shall not attempt to establish this here. Instead, I shall lay out some considerations that each side might invoke in defence of its characterisation of pluralism.

\section{The prospects for engagement}

There are two broad ways of understanding Raz's claims about the competitive nature of pluralism. One relates to human nature, and the other relates to the appropriateness of competition in pluralism independent of facts about human nature.

The first way of understanding the claim about the competitiveness of pluralism is as a claim about human nature: human psychology makes engagement between those who dislike and disapprove of one another, if not impossible, then rare and difficult. If human nature makes certain attitudes inevitable even in the best of conditions then the justification of political principles must not demand that these attitudes are overcome. Human nature means that dislike and disapproval breed repulsion, dismissal, and avoidance, all of which militate against engagement. Raz seems to make this claim in stating that '[c]ompetitive pluralism not only admits the validity of distinct and incompatible moral virtues, but also of virtues which tend, given human nature, to encourage intolerance of other virtues. ${ }^{27}$

This account of the competitive character of pluralism relies on a brute claim about human nature: human psychology makes engagement between those who dislike and disapprove of one another rare and difficult. This sweeping claim will be difficult to defend. But Raz's political perfectionism can be supported by a far more modest claim about the impossibility, or rarity and extreme difficulty, of engagement with disliked or disapproved of others in the political realm in order to discuss questions of justice. If 
this claim is true then any form of political justification reliant on the expectation that citizens will engage in public reason to discuss political questions is threatened.

Such engagement in the political sphere probably is rare and difficult; but the fact that something is difficult does not mean that it is not required or appropriate. Furthermore, it is not clear that the best explanation for this fact is that human nature prevents such engagement at the political level. As Cohen and Rawls point out, liberal political institutions and procedures educate citizens to democratic citizenship. ${ }^{28}$ If human nature is not opposed to engagement per se, they argue, then moving from modus vivendi through constitutional consensus to overlapping consensus brings about changes in citizens enabling them to engage with one another in public reason. The requirement that citizens engage in public reason is most pressing when a democratic political culture has evolved against the background of an overlapping consensus. Although we have not yet experienced a political community that approximates to this ideal, the expectation that citizens engage in public reason can remain central to political justification in virtue of the claim that, by so engaging, people create political institutions that better enable them to engage, and that a political community organised around these institutions is more peaceful and profitable than one without these institutions. On this view, we might argue that the reason why it is rare to find citizens engaging in public reason is not that human nature as it is realised in political life militates against this; rather - being charitable - we might claim that many states have simply failed to move beyond modus vivendi, or have failed to achieve the right constitutional consensus, in which case the conditions in which it becomes easier for people to engage in public reason are missing. As these failures are corrected the expectation that citizens address one another in public reason becomes more insistent, although on this picture the expectation is always legitimate. An alternative, uncharitable, explanation of this failure might be that people are just too lazy and weak-willed to do what is required of them qua citizens.

The second way of reading Raz on competitive pluralism is as making a purely normative claim: the attitudes that thwart engagement are appropriate or desirable independent of any facts about human nature that make these attitudes inevitable. It is hard to envisage an argument for the appropriateness of attitudes that thwart engagement in the absence of claims about how human nature opposes engagement. Such an argument would have to establish that it is appropriate that, for example, soldiers hate students, that corporate raiders sneer at conservationists, and that priests damn prostitutes. Apart from the fact that these are not typical - perhaps not even common - attitudes of the first type of person to the second type, it is not clear in what sense these attitudes could be claimed to be appropriate. Are they morally desirable? Are they necessary virtues of participation in the life to which they attach $?^{29}$ Are they cognitively appropriate to ensure some sort of coherence in a person's mental life? Each of these readings of the 
pure normative claim would be difficult to support, but they all have the same counter-intuitive implication. Soldiers who like students, corporate raiders who praise conservationists, and priests who bless prostitutes fail to have attitudes that they ought to have. Defending this implication on any reading of the pure normative interpretation will be a tall order.

\section{Conclusion}

In conclusion, I have argued that strategies of justification with respect to political principles of toleration and beyond are shaped by conceptions of the character of pluralism, as opposed to conceptions of its nature. This means that assessment of these competing strategies must focus on claims about what can reasonably be expected of persons in conditions of pluralism. Until we have a way of settling this question, the jury must remain out with respect to the question of whether political principles should be justified by reference to a true moral theory, or instead by reference to the imperatives of practical reason as it is exercised by people facing problems of justice in conditions of pluralism.

\section{Notes}

This chapter is based on a paper I presented at the Universities of Reading, Exeter, Manchester, and York. I would like to thank the audiences at each of these events for their comments.

1 For a defence of a form of Constructivism that takes self-respect and its social conditions as a core justificatory value, see my Liberalism and the Defence of Political Constructivism (Basingstoke: Palgrave, 2002).

2 Section 28 began as a Private Member's Bill in 1986, and was eventually passed on 20 February 1988 as part of the Local Government Bill. Section 28 states that: (1) A local authority shall not - (a) intentionally promote homosexuality or publish material with the intention of promoting homosexuality; (b) promote the teaching in any maintained school of the acceptability of homosexuality as a pretended family relationship.

3 The qualification that restraint must be principled to count as toleration separates toleration from indifference.

4 See I. Berlin, 'The pursuit of the ideal', in The Crooked Timber of Humanity (London: Fontana Press, 1990); 'The decline of utopian ideas in the west', ibid.; 'Two concepts of liberty', in Four Essays on Liberty (Oxford: Oxford University Press, 1969). See also J. Raz, The Morality of Freedom (Oxford: Clarendon Press, 1986) and 'Incommensurability and agency', in R. Chang (ed.), Incommensurability, Incomparability and Practical Reason (Cambridge, MA: Harvard University Press, 1997); C. Taylor, 'Leading a life', ibid.; B. Williams, 'Conflicts of values', in Moral Luck: Philosophical Papers 1973-1980 (Cambridge: Cambridge University Press, 1981).

5 Raz writes only of options being incommensurable, but as options involve practices, forms of association, values and beliefs, his account of incommensurabil- 
ity can be extended to cover this range of differences to which personal and political toleration responds.

6 J. Raz, The Morality of Freedom, p. 325.

7 On Berlin's conflation of commensurability and value monism see J. Griffin, 'Incommensurability: what's the problem?', in R. Chang (ed.), Incommensurability, Incomparability and Practical Reason, p. 36; and J. Griffin, Well-Being: Its Meaning, Measurement and Moral Importance (Oxford: Clarendon Press, 1986), pp. 89-92.

8 See Berlin, 'Two concepts of liberty'.

9 For analysis of Berlin's version of this argument see G. Crowder, 'Pluralism and Liberalism', Political Studies, 42:2 (1994) 293-303. See also I. Berlin and B. Williams, 'Pluralism and Liberalism: A Reply', Political Studies, 42:2 (1994) 306-9.

10 See Berlin, 'Two Concepts of Liberty'.

11 J. Rawls, Political Liberalism (New York: Columbia University Press, 1993), p. 226.

12 J. Rawls, 'The idea of public reason revisited', in S. Freeman (ed.), John Rawls: Collected Papers (Cambridge, MA: Harvard University Press, 1999), p. 577.

13 See B. Herman, 'Pluralism and the community of moral judgement', in D. Heyd (ed.), Toleration: An Elusive Virtue (Princeton, NJ: Princeton University Press, 1996), pp. 81-105.

14 Rawls, 'The idea of public reason revisited', p. 580. It is important to be clear that my claims about engagement in public reason do not rest on a conflation of what Rawls calls 'reasoning from conjecture'. A person engaging in this form of reasoning with another attempts to reason from what she conjectures to be the other person's beliefs, values, etc., to a particular conclusion: she can then present this chain of reasoning to the other person as a reason for her to accept this conclusion. See Rawls, 'The Idea of Public Reason Revisited', p. 594. My claim here is rather that for a person to present her own proposals in public reason requires that she attempt to understand the different views of others whom she addresses.

15 Rawls, Political Liberalism, p. 148. That Locke's Letter Concerning Toleration does not consist of arguments made in public reason lends support to Rawls's claim.

16 J. Cohen, 'A more democratic liberalism', Michigan Law Review, 92 (1994) 1503-46.

17 Rawls, Political Liberalism, pp. 164-8.

18 Rawls, ibid., pp. 158-68.

19 Rawls describes the forms of engagement needed for what he calls a 'reasonable moral psychology' in terms of a willingness to propose and abide by fair principles of justice, the maintenance of trust and confidence given sustained and successful social cooperation, and the willingness to participate in social arrangements so as to support them: Political Liberalism, p. 86.

20 Raz, The Morality of Freedom, p. 404.

21 Ibid., p. 405.

22 Raz, 'Multiculturalism: a liberal perspective', in Ethics in the Public Domain (Oxford: Clarendon Press, 1994), p. 165.

23 Raz, The Morality of Freedom, p. 404.

24 See Raz, 'Multiculturalism: a liberal perspective'. 
25 Ibid.

26 'The autonomous person is a (part) author of his own life. The ideal of personal autonomy is the vision of people controlling, to some degree, their own destiny, fashioning it through successive decisions throughout their lives': Raz, The Morality of Freedom, p. 369.

27 Raz, The Morality of Freedom, p. 404.

28 Cohen, 'A more democratic liberalism'; Rawls, Political Liberalism, p. 71.

29 This interpretation is suggested by the following extract from J. Raz, 'Free Expression and Personal Identification', Ethics in the Public Domain: 'A Christian can approve of the way of life of the Muslim, and vice versa ... But not without reservations. There are aspects of the other's practices, attitudes, and beliefs that each of them must take exception to, must disagree with. Disagreement, condemnation, and even hostility to certain aspects of rival ways of life is an essential element of each way of life' (pp. 150-1). See also A. MacIntyre, 'Toleration and the Goods of Conflict', in S. Mendus (ed.), The Politics of Toleration (Edinburgh: Edinburgh University Press, 1999). 